\title{
FESTA POPULAR E EDUCAÇÃO: UM ESTUDO DE CASO SOB AS REFLEXÕES DE ROUSSEAU
}

\author{
POPULAR FESTIVITIES AND EDUCATION: A CASE \\ STUDY BASED ON ROUSSEAU'S REFLECTIONS \\ FÊTE POPULAIRE ET ÉDUCATION : UNE ÉTUDE DE \\ CAS DEVANT LES RÉFLEXIONS DE ROUSSEAU \\ FIESTA POPULAR Y EDUCACIÓN: UN ESTUDIO DE CASO \\ ACERCA DE LAS REFLEXIONES DE ROUSSEAU
}

Wilson Alves de Paiva *

\section{RESUMO}

O texto procura estabelecer uma relação entre o pensamento de Jean-Jacques Rousseau a respeito das festas populares e um festival cultural que se realiza anualmente em um pequeno município do norte brasileiro, como resultado de sua pesquisa de campo. Procura explorar também a atualidade do pensador genebrino com suas idéias de valorizaçāo da sensibilidade, da solidariedade, da liberdade e da igualdade como contraponto à atual desumanização processada pela desigualdade socioeconômica, globalização e mecanização das relaçôes sociais. Por último, o texto busca salientar o papel da educação e, precisamente, das escolas e instituiçôes públicas educacionais na promoção e valorização dos ideais humanos defendidos por Rousseau.

Palavras-chave: Educação. Cultura. Cultura popular. Rousseau.

* Graduado em Pedagogia. Especialista em Psicopedagogia. Mestre em Filosofia Política pela Universidade Federal de Goiás. Doutorando em Educação pela Universidade de São Paulo. Professor da Universidade Estadual de Goiás (wp@riotapajos.com.br). 


\section{"É o povo que constitui o gênero humano; o que não é povo é tão pouca coisa que não vale a pena contar." \\ Rousseau}

\section{INTRODUÇÃO}

O grande pensador Jean-Jacques Rousseau (1713-1778) é bastante conhecido no meio educacional por causa da obra $O$ Emílio, na qual expõe minuciosamente suas idéias pedagógicas. Muitas outras referências são feitas a Rousseau nos estudos políticos, tendo em vista que seu Contrato Social influenciou substancialmente a Revolução Francesa e o estabelecimento do estado moderno, bem como alargou os princípios de liberdade e igualdade política. Aclamado por uns e execrado por outros, em termos gerais o binômio educação e contrato prevalece na constituição de seu pensamento em detrimento de outros aspectos também importantes que o pensador desenvolveu em sua extensa obra. Se os escritos do genebrino formam um todo coerente, como defendem alguns estudiosos (principalmente Ernst Cassirrer em sua obra Le problème Jean-Jacques Rousseau), as minúcias devem ser prospectadas (talvez o termo melhor seria garimpadas) e montadas como num quebra-cabeça. E, reportando-me a Joel Pimentel de Ulhôa, estudioso da obra de Rousseau, ler uma obra sendo "fiel a um filósofo não é apenas lê-lo de forma tecnicamente rigorosa, mas por um processo empático, reviver com ele o problema em torno do qual foi produzido seu discurso e, na medida do possível, aproveitar seu legado na solução de nossos problemas" (ULHOA, 2000, p. 32).

Foi assim que nasceu este artigo: gerado na reflexão de um tema trabalhado por Rousseau de forma esparsa em suas obras, e pouco explorado na atualidade e refletido à luz de um fato empírico, realizado em um município do Norte do Brasil, no sentido de fomentar as discussões em torno da participação comunitária no espaço escolar e refletir sobre a própria participação cidadã do homem moderno.

O tema é o das festas populares, que Rousseau desenvolveu em obras não muito conhecidas, como as Consideraçôes sobre o Governo da Polônia, Carta a D'Alembert, A Nova Heloísa etc., em reação explícita aos espetáculos do teatro francês de seu tempo, cuja pompa e formalismo traduziam o jogo da dissimulação e da aparência existente na sociedade. Essencialmente política, a idéia da festa popular, proposta por ele, nada tem de pomposa ou formal, mas prima pela informalidade, espontaneidade e pela participação coletiva. Nela a realização é comum, favorecendo que os grupos superem suas diferenças sociais, criando um vínculo afetivo importante na formação do espírito de coletividade e de pátria.

Tal é minha comparação com um festival cultural criado em 1993 pela comunidade de estudantes, professores e agricultores do município de Trairão (Oeste do Pará), denominado Arraiarão. Emancipado em 1992 e perdido nas matas amazônicas, isolado pelas condições precárias das vias de acesso e composto por migrantes de diversas regiōes brasileiras, o município deu gênese a um momento de encontro e trocas culturais bem parecido com as festas rousseaunianas. As diferenças, as quais podem ser facilmente detectadas por um estudioso da área, são tratadas neste artigo como apenas nuances 
específicas de um contexto histórico e social bem distinto da época vivida pelo genebrino. São as semelhanças que são destacadas e trabalhadas num sentido de trazer à atualidade uma abordagem perdida nos meandros da racionalidade moderna e nas estruturas frias de um mundo individualista e tecnológico. Serve, portanto, para valorizar o pensamento de um utópico e romântico pensador oitocentista cujas reflexôes se revelam como contrapeso à massificação atual de uma suposta cultura global que prima pelas questôes financeiras em detrimento dos aspectos humanos e culturais que as comunidades criam em sua vida cotidiana e que, no fundo, refletem sua verdadeira dimensão e essência. (Se me disserem que isso é repensar o cerne político do pensamento de Rousseau e atá-lo a uma reflexão pragmática, responderei que chamo isso de filosofar.)

\section{A FESTA E O ESPETÁCULO NO ÂMBITO DA SOCIEDADE}

A sociedade ocidental foi erigida basicamente no princípio aristotélico de que o homem é político, portanto social. O ser humano como um "zoon politikon" não vive isolado e, portanto, cria os vínculos que o unem aos seus semelhantes, propiciando uma vida em comum, no sentido de suprir suas carências (ARISTÓTELES, 2000, p. 147). Nessa perspectiva, desde o primeiro núcleo humano, que é a família, até a mais ampla organização social, que é o Estado, a vida em sociedade se forma a partir de uma necessidade natural. O que os antigos gregos chamaram de polis é o ajuntamento das famílias e aldeias em um grupo maior que busca algo mais que simplesmente suprir as necessidades imediatas, mas sua auto-suficiência e o aperfeiçoamento humano por meio da teia de relações comunitárias, das quais a justiça desponta como o maior vínculo social. Sem tais vínculos, tendo em vista que são naturais, o homem perde-se em sua bestialidade e se torna o pior dos animais.

A tradição jusnaturalista, por sua vez, defende uma ordem de princípios eternos, absolutos e imutáveis, ou seja, princípios aos quais o homem está atado desde seu nascimento e que nenhuma lei pode alterar. Independente da vida em sociedade, o homem já tem, de forma intrínseca, alguns direitos, como o direito à vida, à liberdade, à justiça, à propriedade etc. O Jusnaturalismo Moderno de Hugo Grócio, Pufendorf, Hobbes, Rousseau, Locke e outros representa uma ruptura com o Jusnaturalismo Clássico e com o Jusnaturalismo Escolástico, desligando-se de seus fundamentos ontológicos e teológicos e possibilitando um novo humanismo, que, mesmo cético e pessimista, propiciou uma mudança de conceito do que seria natural, tanto em relação aos clássicos e escolásticos como ao próprio conceito de Aristóteles (384-322 a.C.) do tão conhecido zoon politikon. Enquanto os vínculos da vida social são naturais para o estagirita, o jusnaturalista Thomas Hobbes (1588-1679), por exemplo, defende que o homem perde-se em sua bestialidade pela própria natureza. Para ele, os vínculos que impedem os homens de sucumbirem a uma total guerra entre si, pelo fato de não serem naturalmente sociais, devem ser impostos por um poder superior cuja força de um pacto, e conseqüentemente de uma espada, promovam o bem comum.

Numa visão radical, nenhum dos jusnaturalistas se desvincula totalmente do edifício aristotélico, pois, como observa muito bem Rousseau, "todos, falando incessantemente de necessidade, avidez, opressão, desejo e orgulho, transferiram ao estado de natureza 
idéias que nasceram na sociedade. Falavam do homem selvagem e descreviam o homem civil" (ROUSSEAU, 1989, p. 49).

É precisamente nesse aspecto que Rousseau se destaca dentre os pensadores citados, porque elabora uma reflexão bastante original acerca do homem natural. Com um fundo essencialmente cristão (da corrente luterana e calvinista), a tese de Rousseau é que o homem nasce bom por natureza, não no sentido exatamente cristão, e poderia ter vivido eternamente num estado paradisíaco se suas paixôes e alguns acidentes naturais não tivessem gerado a vida social. É na sociedade que se efetua sua queda, uma vez que se entrega ao amor próprio, à vaidade, à ilusão, à dissolução, à intriga, à inveja etc. Ou seja, os homens tornam-se, ao contrário do que Hobbes defende, desumanos. O homem de Rousseau é pré-societário, pré-histórico e a-político. Deseja apenas viver livre sob os carvalhos em contato direto com a natureza, num profundo amor de si mesmo (amour de soi) e na piedade para com seus semelhantes (pitié).

No entanto, Heck (1997, p. 56) afirma que "o ideário revolucionário de Rousseau não passaria de um aristotelismo requentado e o filósofo esconderia um lobo sob sua pele de ovelha". Afinal, acaba admitindo a sociedade como um estágio inevitável e oferece seu contraponto natural como ação política reacionária ao status quo.

Admitindo, dessa forma, que o estado de natureza talvez nunca tenha existido e provavelmente nunca existirá, e que a realidade nua e crua é um estado social de desigualdades, injustiça e falsidade, não se trata de buscar um retorno id́líico ao estado natural perdido, nem tampouco de conservar a primazia dos sentimentos da natureza. Trata-se de melhor desnaturar o homem, tirando-o de sua unidade isolada e única e colocando-o numa unidade comum, num todo coeso e social, corrigindo as discrepâncias sociais. Todavia, ao contrário do que muitos podem pensar, essa tarefa não cabe à educação (enquanto ação individual e não institucional, como descrita no Emílio), mas cabe integralmente ao efeito do pacto social e da alienação total dos contratantes.

Mesmo havendo um caráter pedagógico na ação social desnaturadora, a presente reflexão se limita à feição antropológica da vida social e à efervescência da cultura popular que nela subsiste e acaba revelando nuances do estado de natureza e semelhanças com um período hipotético que a humanidade poderia ter vivido antes da organização em sociedade como a entendemos hoje. Limita-se, mais precisamente, à análise da festa popular em paralelo com o espetáculo teatral.

Apesar de ter escrito óperas e comédias para teatro, Rousseau voltou-se terrivelmente contra essa arte, fazendo dela a metáfora da perversão humana, uma vez que nela encontramse dois males que desnaturam o homem degradando-o: o espetáculo e a representação. Estamos, neste ponto, no cerne do pensamento de Jean-Jacques, que vê na representação a cisão do homem entre ser e parecer, e, por conseguinte, a perda de sua essência (enquanto homo naturalis) e sua existência (enquanto homo politicus) em pura dissimulação. No espetáculo, por sua vez, Rousseau vê o aprofundamento da desigualdade social e a expressão das intenções universalistas da classe burguesa com seu ego narcísico. $\mathrm{O}$ espetáculo emudece a massa de cidadãos, que, engodados pela ostentação do luxo e da imaginação de um pequeno e seleto grupo de "nobres", limitam-se a contemplar e voltar a sua posição de subalternos, de simples objetos. $\mathrm{O}$ que acontece aqui é a imposição autoritária de um conjunto de representaçôes e normas próprias dessa elite. Marilena 
Chauí (1988, p. 121) fala que "o autoritarismo existe sempre e cada vez que as representaçôes e normas pelas quais os agentes sociais e políticos interpretam suas relações sejam representaçôes e normas vindas do exterior e do alto".

Contra exatamente tal aspecto e ainda enojado da pompa e da exposição ostensiva do luxo e das máscaras que artificializam as relações humanas nos espetáculos teatrais de sua época, Rousseau vai buscar na simplicidade da vida campestre o refúgio de suas reflexões:

Impressionamo-nos com a felicidade de certas condiçōes, como por exemplo da vida campestre e pastoral. O encanto de ver essa boa gente feliz não é envenenado pela inveja; interessamo-nos por ela verdadeiramente. Por quê? Porque nos sentimos capazes de descer a essa condição de paz e de inocência, de gozar a mesma felicidade; é uma solução que só dá idéias agradáveis, porquanto basta querer gozá-la para o poder (Emílio, p. 246).

É nessa condição de paz e de inocência que o moralismo rousseauniano toma suas matizes para eleger a festa camponesa, ou popular, ${ }^{1}$ como paradigma de vida social. Se no teatro alguém vive no nosso lugar e se apresenta num tablado acima de todos e para quem todas as atençôes devem convergir, na festa comunitária todos participam igualmente e se divertem em danças coletivas numa fusão completa de cores, gestos, faces, figuras e condição material, convergindo as atenções para si mesmos. Muito além de uma simples análise estética, a teoria da festa "é uma visão de reconciliação da existência parcial do homem e de seu ser total encarnado numa comunidade" (FREITAS, 2003, p. 43). Ou seja, é a recusa de uma essência coletiva encarnada no pequeno grupo que se apresenta em espetáculo.

Substancialmente política, a visão de Rousseau sobre as festas populares possibilita uma nova dimensão espaço-temporal na qual podemos prospectar a gênese de uma nova natureza. Aqui o ser natural deixa de ser o indivíduo para ser a coletividade, na qual todos têm a liberdade de participar ativamente da dinâmica de sua existência. É, pois, o espaço propício para as relações realmente afetivas, sinceras e justas, onde a sensibilidade é aguçada. Além do mais, predomina a liberdade e o aperfeiçoamento (ou perfectibilidade) das paixôes naturais, ou seja, do amor de si mesmo e da comiseração (amor ao próximo).

Nessa perspectiva, a festa popular torna-se a reconstituiçãao da unidade perdida, ${ }^{2}$ porque coloca o homem (agora incorporado no todo social) em contato mais uma vez com o ar livre, o céu, a liberdade do campo e com a beleza das cores, tanto das flores, como das vestes simples das camponesas. O movimento do ir e vir, as danças e a própria música tornam-se uma comunicação real, espontânea e sem mediação discursiva e regras pré-fixadas. A máscara do espetáculo dá lugar ao sorriso afável e às gargalhadas de uma alegria anormal. A felicidade (uma das preocupações primordiais de Rousseau) tem plena possibilidade de se realizar nessa coexistência festiva em que todos sejam iguais e que dispensem toda espécie de mediação e representação entre eles.

Como o verdadeiro debate político se dá entre as instituições e não entre indivíduos isolados, Rousseau faz do povo reunido, vale dizer deliberadamente reunido, uma instituição política por excelência. Nesse encontro o debate é desinteressado, mas fluido e autêntico; ele gera valores comuns e fazem despertar o interesse do povo por si mesmo, ou seja, ele fomenta o desenvolvimento do amor de si, de sua auto-valorização, auto- afirmação e 
auto-colocação no âmbito da participação social e política. O diálogo presente nas festas populares não é, com certeza, o debate que se realiza nos partidos, na mídia e nas instâncias governamentais, mas o diálogo descomprometido, no qual o povo compartilha suas dores e seus problemas pessoais, os quais na maioria das vezes têm uma ligação direta com as políticas do Estado. Desse diálogo simples e descomprometido brota a Vontade Geral, por ser o substrato comum da consciência de cada indivíduo livre inserido na multidão. Rousseau inicia o Livro Quarto do Contrato Social dizendo que: "Enquanto muitos homens reunidos se consideram um único corpo, eles não têm senão uma única vontade que se liga à conservação comum e ao bem-estar geral" (p. 199).

Nesse aspecto talvez Rousseau realmente acabe despindo sua pele de ovelha, como afirma Heck (1997), e fomente uma discussão que possa atingir a subversão do status quo. Não é à toa que seus elementos principais tenham servido de inspiração à Revolução Francesa, à Independência dos Estados Unidos etc., e mesmo à elaboração de teorias igualitárias, como o socialismo de Marx, Engels e Lênin. Mas suas reflexões nos permitem também deslocar o eixo do estritamente político para o eixo antropológico e cultural, no qual a dita subversão toma um caráter distinto dos atos revolucionários ocorridos na França, na Rússia, em Cuba e em outros rincões. Ou seja, subverter o status quo do homem moderno cujos parâmetros de cientificidade, massificação, globalização e financeirização das relações sociais possam receber contribuições de alguns elementos perdidos ao longo do tempo: a solidariedade, o amor, o comunitarismo e a valorização das fontes culturais e históricas que revelem a alma do povo, ${ }^{3}$ que revelem sua verdadeira riqueza e lhe abram espaço para uma participação mais cidadã nos destinos de sua própria comunidade.

Levantar essas questóes pode parecer paradoxal na atualidade, uma vez que o que testemunhamos é uma globalização econômica e cultural massificante na qual os aspectos locais e regionais são preteridos em favor de uma suposta universalidade de valores. Por outro lado, o movimento de industrialização do campo tende a desmantelar as comunidades rurais e provocar uma urbanização acelerada. Testemunhamos também um desmantelamento das solidariedades tradicionais de vizinhança e de comunidade, bem como uma profunda crise moral e ética nas relações entre os indivíduos. No entanto, longe de ser paradoxal, chegamos à conclusão de que a utopia rousseauniana pode nos ajudar na busca de um mundo diferente.

Justificada dessa forma, a reflexão deve ser enriquecida com um estudo de caso. E partir a campo num país de múltiplas realidades, como o Brasil, não é tão difícil assim. Até porque coexiste uma realidade caipira no contexto brasileiro, e nos recônditos ermos da vida interiorana encontram-se comunidades que lutam por preservar suas culturas ${ }^{4}$ ou mesmo buscam criar situaçóes em que a verdadeira alma do povo (loc. cit.) se manifeste de forma livre e espontânea. É o caso do município no qual desenvolvi ao longo de quase quatro anos (1993 e 1998-2000) um estudo de seu festival cultural do qual resultaram estas reflexões.

E ao fazer essa espécie de estudo etnológico, escoro-me em Lévi-Strauss (1972, p. 9) que considera Rousseau o criador da Etnologia. Dessa forma, posso afirmar que a obra rousseauniana possibilita uma maior compreensão do outro e, acrescidos os elementos políticos de suas reflexôes, enriquece o grande debate que ata a política, a cultura e a educação em um só molho. 


\section{O CASO ARRAIARÃO}

Rousseau preferia sua pequena Genebra às grandes cidades da época, como Paris. Constantemente se instalava em propriedades campestres no sentido de estar sempre em contato mais próximo com a natureza e evitar a ostentação e o luxo da vida urbana. Agindo dessa forma, procurava fugir da crua realidade social, que oferecia um quadro não muito alentador, tendo em vista as desigualdades sócio-econômicas, a ostentação do luxo, a artificialidade das relaçôes humanas, entre outros aspectos. No mesmo sentido, a intensa movimentação migratória rumo ao norte brasileiro que se efetivou a partir das décadas de 1970 e 1980 também se reveste de significações importantes para a análise em que estamos. Por um lado, tendo em vista a modernização e industrialização tardia da sociedade brasileira e o desenvolvimento de uma cultura rural ao longo dos séculos, jaz latente no imaginário popular uma idealização pelo campo que relembra os tempos coloniais. A pequena propriedade na qual toda a família se envolve nas atividades produtivas durante o dia, toma banho nas águas do riacho próximo à tardezinha e à noite se reúne em torno de uma fogueira ao luar ou mesmo em torno da mesa servida de sopa sob o teto de uma choupana perdida na escuridão do campo é um aspecto que sobreviveu até o século XX como cenário comum da vida brasileira e ainda sobrevive em alguns rincões do território. Representa, dessa forma, a busca do paraíso perdido e o reencontro do homem com a natureza e com as possibilidades ilimitadas de realização e liberdade. Acrescenta-se, por outro lado, a fuga da urbanização, do desemprego, da pobreza e da falta de espaço para realização pessoal em sua identidade de homem caboclo, de homem da terra, da viola, das fogueiras e dos 'causos' não registrados. ${ }^{5}$

A visão idílica de Rousseau a respeito da pequena comunidade se aproxima muito da aglomeração que se realizou às margens do Igarapé Amadeus. Perdido por entre as matas do Oeste do Pará, o pequeno riacho congregou sulistas, nordestinos e pessoas de outras regiōes numa convivência pacífica e comunitária. Em 1985, já com três ruas e pouco mais de trinta casas, conheci o local e testemunhei o modo de vida simples dessa população. À noite, as lamparinas e os sotaques diversos se entrecruzavam por entre os arbustos e as poças de água em busca de uma roda de chimarrão ou de um pequeno grupo de pessoas em alegres conversas nas varandas ou salas das pequenas casas. Todos se conheciam e era possível detectar entre eles um espírito de solidariedade e compaixão que se revelava em diversas situaçōes, principalmente nas ocasiōes de chegada de um novo morador, quando ajudavam com víveres, doação de diárias na construção do barraco e de outras formas.

O crescimento que se verificou a partir daí e até o início dos anos 1990, principalmente com a exploração comercial de madeira e cacau e com a criação do município em $1991,{ }^{6}$ não mudou muito seu modus vivendi, de tal forma que o espírito de comunidade possibilitou a criação do festival.

Embora não sendo uma festa tipicamente popular, nos moldes que Rousseau propõe, ou seja, uma agregação espontânea sob a sombra de uma grande árvore ou diante de rústicas cabanas e em cujo local a presença pura e simples do povo venha a ser suficiente para haver um ato festivo, o Festival Folclórico Cultural de Trairão - Arraiarão - possui muitos elementos que o aproximam desse ajuntamento livre e descomprometido idealizado pelo filósofo. Pensada por um número bem reduzido de três ou quatro pessoas (no papel 
de pedagogos sociais) em 1993, a idéia teve inúmeros simpatizantes entre professores, estudantes e agricultores em geral, dos quais formou-se uma grande equipe organizadora que passou a se reunir periodicamente no sentido de discutir as atividades a serem desenvolvidas. Embora haja a mediação da equipe na coordenação e realização do evento, a atmosfera que se cria nos dois ou três dias de acontecimento da festa evoca um sentimento de liberdade, entrosamento, comunhão e alegria. A ação diretiva da equipe deve ser vista como um ato de intervenção necessário à busca de uma coesão entre uma comunidade formada de pessoas com características étnicas, culturais e espirituais bastante distintas. É ciente dessa peculiaridade que Rousseau reconhece a mediação do Legislador, no Contrato Social e a presidência da Sra. d'Orbe ${ }^{7}$ nos festivais das vindimas, onde o encontro dos agricultores para comemorar a colheita do ano proporciona um prazer natural e, com isso, as manifestações livres da alma através do canto, da dança, das refeições e de toda movimentação do corpo numa dimensão de igualdade e fraternidade.

Realizado uma vez por ano, o Arraiarão também proporciona um espaço e um momento de encontro entre agricultores que, apesar das diferenças sociais e econômicas, tiveram em sua história de migração a mesma experiência de vida, os mesmos sofrimentos, temores, dificuldades e todos lutaram contras as mesmas intempéries da natureza virgem. Mesmo havendo diferenças econômicas, sociais e culturais, o festival se tornou um instrumento bastante eficaz para transformar essas diferenças em algo positivo. Nos dias de realização da festa os agricultores são estimulados a irem vestidos com roupas típicas de sua região de origem. Ou seja, o gaúcho de bombacha, os nordestinos de chapéu de couro e assim por diante. No ano de 1999 e 2000 o festival contou com cinco grandes barracas onde eram feitas comidas típicas de cada região brasileira. Na barraca do nordeste, por exemplo, havia exposição de objetos trazidos pelos migrantes e eram servidos vatapá, acarajé, entre outras iguarias. Semelhantemente, as outras barracas serviam seus pratos típicos, como o churrasco e o chimarrão, na barraca do sul.

Durante todo o evento, diversas apresentaçôes culturais organizadas pelos estudantes do ensino fundamental e médio (com participação de agricultores que não são estudantes) abrilhantam o festival e ajudam a desenvolver sua própria identidade e fortalecem o sentido cívico de comunidade. Ao apresentar a dança-de-fitas e promover concurso de sanfoneiros e repentistas, o festival contribui com a preservação dos traços culturais do povo e solidifica suas raízes. Sendo impossível negar as distintas características dos habitantes do município, é importante transformar isso em contribuições para uma comunidade diversificada culturalmente, mas unida e coesa em seus objetivos cívicos.

Assim como o Legislador tem um papel pedagógico no sentido de suscitar o amor à pátria, é, em nosso caso, o festival que executa essa tarefa. Se não é possível prescindir-se do espetáculo, que seja então para exaltar os valores culturais da comunidade, bem como desejava Rousseau na festa cívica.

No entanto, é digno notar que, apesar da movimentação, do colorido e do som agradável das danças, dos concursos de música, de quadrilhas juninas, de repentistas, e de outras apresentações várias, percebe-se que a atenção das pessoas está mais ligada ao movimento daqueles que não participam de nenhum espetáculo. Ou seja, daqueles que se sentam à roda de uma mesa em frente às barracas típicas para comer e conversar, bem como daqueles que circulam de forma descomprometida. Mesmo que não houvesse 
nenhuma apresentação artística, haveria um bom número de pessoas nesse envolvente encontro em que todos se sentem parte de uma comunidade cuja dinâmica está expressa em todos os momentos e atividades do festival, próximo ao ideal de festa cívica e festa popular pensada pelo genebrino.

Rousseau relata a festa primitiva da seguinte forma:

No inverno o musgo e a casa das árvores eram nossos alimentos habitais; algumas raízes verdes de grama e de urzes eram para nós um regalo; e quando os homens conseguiam encontrar faias, nozes ou bolotas, dançavam de alegria ao redor de um carvalho ou de uma faia ao som de alguma canção rústica, chamando à terra sua nutriz e sua mãe; era sua única festa; eram seus únicos jogos; todo o resto da vida humana não passava de dor, pena e miséria (Emílio, p. 159160 , o grifo é meu).

Não resta dúvida quanto à situação hipotética desse encontro, bem como de todo o estado de natureza imaginado por ele. No entanto, a realidade inicial do município de Trairão oferecia um quadro parecido. Ao adentrarem a mata virgem, os agricultores se estabeleceram de forma rústica em pequenos ranchos ou mesmo tendas cobertas de folhas ou capim. Suas atividades resumiam-se a: desmatamento manual (a machado), caça, pesca e plantio. Sendo essa a realidade de muitos até o ano de 1993, podemos dizer que, além de alguns raros torneios de futebol e algumas insalubres celebraçōes católicas, o Arraiarão se tornou, em termos comunitários, a única festa.

Considerando também que a visão de liberdade e felicidade vem à tona de forma "depurada" na festa cívica descrita na Carta a d'Alembert e que nesse novo encontro o indivíduo se exalta na liberdade coletiva e goza de uma igualdade que se manifesta na dinâmica do próprio evento, o festival trairense também depurou-se ao se transformar em uma espécie de festa cívica cujo objetivo precípuo deixou de ser o simples ajuntamento e passou a ser um esforço de valorização e preservação das culturas do povo, bem como a construção da identidade cultural do município.

No aspecto pedagógico o Arraiarão foi criado também com vistas a proporcionar uma participação ativa dos estudantes não apenas em sua organização, mas também nas apresentaçōes culturais. Com isso, as escolas passaram a desenvolver a arte e a valorizar as manifestações folclóricas com seus alunos, bem como resgatar as origens históricoculturais dos habitantes do município. As danças desenvolveram o aspecto lúdico e trouxeram mais alegria à escola. Como a atividade pedagógica transcende a sala de aula, a própria população em geral se tornou mais consciente de suas raízes e mais conhecedora de suas próprias manifestações culturais, bem como das manifestações de outras regiōes brasileiras. $\mathrm{O}$ caso da apresentação individual de repentistas, sanfoneiros, cantores, artesãos e grupos de dançarinos no Arraiarão pode parecer paradoxal e até mesmo atentar contra a unidade e a igualdade, dentro do pensamento de Rousseau. ${ }^{9}$ No entanto, não podemos esquecer que se trata de apresentaçôes simples, relacionadas ao cotidiano da própria comunidade, e que: primeiro, desenvolvem a sensibilidade e o respeito para com suas próprias manifestações culturais; segundo, a pessoa que se apresenta em espetáculo é, muitas vezes um simples agricultor ou estudante que volta a suas atividades rotineiras após o festival; e, por último, ao valorizar os elementos culturais, o evento contribui com 
a construção do corpo político. Ou seja, a reabilitação dos signos e da representação tem um propósito político que não foge da filosofia política do filósofo.

$\mathrm{Na}$ verdade, a festa tipicamente rousseauniana, melhor dizendo, a festa primitiva, serve de referencial contra a ostentação aristocrática de sua época; e hoje contra a elitização da cultura. Rousseau deseja reunir o povo inteiro ao ar livre (e não nos salóes palacianos), porque essa espécie de práxis coletiva se transforma em uma verdadeira comunicação social, autêntica, direta e que revela a igualdade natural dos seres humanos. Se isso se realizar numa festa republicana ou num festival, como ocorre no município de Trairão, não foge de seu ideal, até porque se aproxima do "grau mínimo" de representatividade e do "grau máximo de fusão e simbiose comunitária", ${ }^{10}$ aceitos por Rousseau nas festas cívicas.

Ou seja, em termos práticos o primitivismo rousseauniano não existe. Mas longe de ficarmos perdidos num labirinto utópico, suas reflexōes desnudam a artificialidade das relações humanas e se revelam como referencial valioso ao mundo moderno, cujas raízes populares, comunitárias e humanizadoras se perdem a cada dia.

\section{O QUE TIRAMOS DE TUDO ISSO}

Quero iniciar esta parte conclusiva com uma citação de Carlos Rodrigues Brandão que nos remete a um dos aspectos mais importantes desse contexto e que quero tentar desenvolver. $\mathrm{O}$ autor diz que:

...assim como uma ação pedagógica intencionada pode transformar a cultura do povo em uma verdadeira cultura popular (algo equivalente à passagem da classe-em-si a classe-para-si ou, em termos mais atuais, à passagem do povo de sujeito econômico a sujeito político), a ação de uma qualidade de cultura pode modificar a qualidade de uma outra (BRANDÃO, 2002, p. 112).

Podemos dizer que a sociedade acabou trocando o zoon politikon pelo homo oeconomicus como ideal a ser buscado e preservado. A dimensão econômica passou a ter mais relevância nas relações sociais, humanas e culturais, vivemos um período de fetichização da mercadoria e a produção humana se tornou um movimento mecânico, ${ }^{11}$ o dinheiro se revelando como o mais importante vínculo social e humano. ${ }^{12}$

O homem de raízes caboclas, de vida campestre e costumes simples tornou-se uma categoria em extinção no contexto em que vivemos. ${ }^{13}$ Sua riqueza cultural não é reconhecida e devidamente explorada pelas organizações políticas. Como acentua bem Octávio Ianni, é preciso sair do discurso ${ }^{14}$ e tomar medidas concretas em nossas políticas públicas no sentido de valorizar as culturas do povo.

A promoção do turismo folclórico, como ocorre na festa do boi de Parintins (AM) e nas festas religiosas católicas, está mais para o espetáculo das máscaras, que Rousseau repudiava, que para a festa do povo relatada aqui.

Portanto, resta à pedagogia política e à política pedagógica tentar resgatar os traços de uma humanização sem espaço nos caminhos positivistas que a modernidade tem tomado. No campo da política, essa tarefa deve fazer parte das metas e ações do governo (seja municipal, estadual ou federal) e constar em seus planos de políticas públicas, 
revestindo-se cada vez mais de um caráter pedagógico, no sentido de formar um outro tipo de cidadão, ou seja, o cidadão capaz de entender a si mesmo (suas raízes) e ao próximo, valorizando o inter-relacionamento das pessoas como seres dotados de uma riqueza que não pode ser dispensada na construção do espaço social.

No campo da política pedagógica, deve-se bater de frente contra as intenções unilaterais de uma suposta globalização cujo processo acaba, na verdade, dizimando culturas locais. Tal processo faz com que se percam as noções de igualdade, solidariedade e justiça social como fatores preponderantes da discussão e do espaço público e cedam lugar a noções mercadológicas do tipo: qualidade total, eficiência, produtividade como chaves para uma suposta pós-modernidade.

As secretarias municipais de educação e as próprias escolas possuem um papel importante dentro de um contexto de descentralização e municipalização que experimentamos nos dias atuais. ${ }^{15}$ Assim como a Semec (Secretaria Municipal de Educação, Cultura, Desportos e Turismo) de Trairão tem apoiado substancialmente o festival, juntamente com todas as escolas do município, com uma verba mínima, que o exemplo nos instigue a todos na promoção e valorização das culturas populares em geral. $O$ respeito à fala cabocla, por exemplo; o aproveitamento dos saberes populares de um raizeiro, da alegria de um violeiro ou sanfoneiro, da experiência de vida de um agricultor sofrido ou de um operário urbano e outras figuras não menos importante que se incluem na categoria povo são excelentes instrumentos pedagógicos na construção da aprendizagem (pelo viés construtivista), na promoção da cidadania (pelo viés socio-interacionista) e na formação do homem político por excelência como sujeito de sua própria existência. $\mathrm{O}$ papel da descentralização deve ser tomado com uma oportunidade única de se pensar as questôes locais, dando-lhes mais sentido.

É bem certo que essa ação intencional pode ser interpretada como diretivista, representativa e não autenticamente popular. No entanto, analisando o sistema democrático atual, a ação da comunidade toda só se manifesta por intermédio da representatividade. Mesmo assim o cidadão pode ser considerado ativo e participante quando age no governo ao ser eleito a um cargo em um dos poderes constituídos e quando participa nas tomadas de decisão em níveis menos hierarquizados e institucionalizados, como na associação de bairro, na associação de pais e mestres, no grêmio estudantil, entre outras. Muito além disso, o cidadão é ativo também quando "pensa os problemas políticos, independentemente de qualquer militantismo, é ativo ao participar da discussão em qualquer lugar que seja" (CANIVEZ, 1991, p. 156). E é neste aspecto que entra o papel do educador como o elemento político ao ajudar aos outros na compreensão dos problemas, na discussão das causas e na formação de uma opinião pública que favoreça as classes populares e lhes dê uma consciência política e uma responsabilidade social. Nessa perspectiva a escola é ativa, porque prepara o cidadão ativo dando-lhe o gosto pela discussão, pela reflexão dos problemas sociais existentes in concreto.

No entanto, levar para a sala de aula ou a qualquer espaço onde se processam relações culturais e educacionais a militância partidária, sectária e político-arbitrária é, apesar do alto grau de boa-fé, inculcar nos educandos um tipo de comportamento inautêntico e deliberadamente autoritário. 
Se tomarmos como ponto de partida que a cultura oficial é alienante, a desalienação não se processa por meio de uma imposição de uma espécie de contracultura ou cultura de resistência criada a partir de pressupostos teóricos. A resistência se dá justamente nas tramas daquilo que flui do contexto da convivência humana e de suas trocas simbólicas. Parafraseando Gadotti (Cf. nota 15), não se pode ganhar uma luta senão estando nela totalmente inserido e tentando mudar-lhe o sentido.

Tomando a festa, segundo Salinas Fortes (1997, p. 191), como paradigma "para a própria ordenação global da vida pública", a lição de Rousseau nos ensina a mediar as relaçōes sociais com menos formalidade e mais espontaneidade, mais solidariedade, mais espírito comunitário e com uma real valorização do povo como a categoria social que sofre a discriminação de serem pobres, simples e "rudes".

A escola tem uma dívida social e histórica com essa classe. As instituições escolares devem aprender com as festas rousseaunianas e com o Arraiarão a dispersar as facções, as diferenças étnicas, culturais e econômicas, não de forma momentânea e espetacular como o faz o carnaval brasileiro (DA MATTA, 1990), mas de forma duradoura, através de seu projeto político-pedagógico e de todas suas ações. Como diz Carmen Cinira Macedo, ${ }^{16}$ "no cômputo geral, fica a idéia de que não basta o reconhecimento da necessidade de se aliar aos de baixo: é preciso viabilizar a aliança e, sobretudo, torná-la fértil. Essa a grande questão em aberto, o grande desafio".

Considero desafio porque, assim como na época de Rousseau suas observações e reflexões foram tomadas como esdrúxulas, contraditórias e irracionais, falar hoje de sensibilidade, amor (como falou Paulo Freire), solidariedade, espírito comunitário etc., pode parecer paradoxal numa sociedade individualista, materialista e cientificista na qual poucos se dedicam a falar de tais assuntos. Quem, no meio acadêmico, dedica-se ao estudo do amor, a não ser alguns gurus da auto-ajuda no meio educacional? Quem ousa falar de brasilidade de forma otimista e positiva sem ser tachado de ufanista? Quem tem a coragem de falar contra a excessiva valorização de festas como o Halloween, em detrimento das comemorações caboclas, sem ser rotulado como retrógrado?

Estas e outras questôes nos remetem à atualidade de Rousseau e à importância de sua obra. O estudo de caso aqui descrito revela a possibilidade e a exeqüibilidade das reflexões do autor do Emílio.

Concluindo, quero encerrar com a fala da Comissão Internacional sobre Educação para o século XXI, no relatório elaborado para a Unesco, mais conhecido como Relatório Jacques Delors, que diz:

Devemos cultivar, como utopia orientadora, o propósito de encaminhar o mundo para uma maior compreensão mútua, mais sentido de responsabilidade e mais solidariedade, na aceitação das nossas diferenças espirituais e culturais. A educação, permitindo o acesso de todos ao conhecimento, tem um papel bem concreto a desempenhar no cumprimento desta tarefa universal: ajudar a compreender o mundo e o outro, a fim de que cada um compreenda melhor a si mesmo (DELORS, 2003, p. 50). 


\section{Notas}

1. Entre o estado de natureza, estágio de isolamento em que o homem bastava a si mesmo, e o estado de sociedade existe um estágio intermediário que Rousseau chama de "Idade do ouro" no qual os indivíduos se encontram e festejam. No entanto, essas "festas primitivas" não têm um atributo associativo, mas meramente agregador. A festa popular se realiza no estado social e vai além de uma simples relação física, ela conduz à troca e promove a união do corpo coletivo.

2. Como afirma Freitas (2003, p. 87) como título do terceiro capítulo de seu livro.

3. Expressões de Paulo Freire em seu livro: Cartas a Guiné-Bissau.

4. O conceito de cultura que utilizo está muito bem formulado em Brandão (2002, p. 220-221): "Portanto, a cultura não é uma dimensão da vida social, a do significado, constituída por trocas sociais específicas deste domínio que ela própria significa. Ela é aquilo que há de operativamente significante em qualquer dimensão social de trocas e de transformaçôes."

5. Salvo por intelectuais que como Bento Jayme Fleury Curado (1998) no livro Ser(tão) goiano, dedica-se a valorizar e registrar os 'causos' caipiras do interior goiano.

6. Criado em 13/12/91 através da Lei. 5.695/1991.

7. Relato da obra Nouvelle Héloise. Apud: Freitas: 2003, p. 106-107.

8. A expressão é de Mona Ozout, citado por Fortes, 1997, p. 181.

9. A apresentação individual ou de grupos separados acaba se tornando espetáculo, distanciando alguns da igualdade geral. Tal deslocamento social faz nascer e desenvolver o amor-próprio, o orgulho, a inveja e, enfim, a valorização de uns em detrimento de outros.

10. Expressōes de Fortes, 1997, p. 183.

11. Cf. MARX, K. Manuscritos económico-filosóficos, p. 166.

12. Idem, p. 169.

13. Cf. O texto comentário "cultura do povo e autoritarismo das elites", de Octavio Ianni, in: VALLE, E. et al. A cultura do povo. São Paulo: Cortez, 1988, p. 134-144.

14. Idem, p. 136.

15. Há muitos que não concordam com esta minha proposição, tendo em vista o caráter de reprodução ideológica (Cf. Althusser, L. Os aparelhos ideológicos...) das instituiçóes educacionais e do caráter de desconcentração do ensino no Brasil. Quanto a essa discussão, remeto o leitor a um outro artigo meu, publicado pela revista Presença Pedagógica (artigo da capa), v. 8, n. 48, de nov./dez. de 2002. Nesse artigo, cito a fala de Moacir Gadotti o qual afirma que "só se pode ganhar uma luta se entrarmos nela, tentando modificar-lhe o sentido" (Apud PAIVA, Wilson, 2002, p. 60).

16. Cf. As Consideraçōes Finais do debate que gerou o livro: VALLE, Edênio et al. A cultura do povo. São Paulo: Cortez, 1988. 


\section{Referências}

ARISTÓTELES. Política. Trad.: Therezinha Monteiro Deutsch Baby Abrão. São Paulo: Nova Cultural, 2000 (Coleção Os Pensadores).

BRANDÃO, Carlos Rodrigues. A educação como cultura. Campinas: Mercado de Letras, 2002.

CANIVEZ, Patrice. Educar o cidadão? Trad.: Estela do Santos Abreu e Cláudio Santoro. 2. ed. Campinas: Papirus, 1991 (Coleção Filosofar no Presente).

CASSIRRER, Ernst. Le problème Jean-Jacques Rousseau. Traduit de l'allemand par Marc B. de Launay. Préface de Jean Starobinski. Paris: Hachette, 1987.

CHAUÍ, Marilena. Cultura do povo e autoritarismo das elites. In: VALLE, E. et al. A cultura do povo. São Paulo: Cortez, 1988, p. 119-134.

CURADO, Bento Alves Araújo Jayme Fleuri. Ser(tão) goiano. Goiânia: Kelps, 1998.

DA MATTA, Roberto. A casa e a rua. Rio de Janeiro: Koogan, 1991.

Carnavais, malandros e heróis. para uma sociologia do dilema brasileiro. Rio de Janeiro: Koogan, 1990.

DELORS, Jacques (Org.). Educação, um tesouro a descobrir. relatório para a Unesco da Comissão Internacional sobre Educação para o século XXI. 8. ed. São Paulo: Cortez; Brasília: MEC e Unesco, 2003. FORTES, Luiz Roberto Salinas. Paradoxo do espetáculo: política e poética em Rousseau. São Paulo: Discurso Editorial, 1997.

FREIRE, Paulo. Cartas à Guiné-Bissau. 3. ed. Rio de Janeiro: Paz e Terra, 1978.

FREITAS, Jacira de. Política e festa popular em Rousseau: a recusa da representação. São Paulo: Humanitas, 2003.

GENTILI, Pablo; SILVA, Tomaz Tadeu da (Orgs.). Neoliberalismo, qualidade total e educação: visões críticas. 9. ed. Petrópolis: Vozes, 2001.

HECK, José N. Ceticismo e trabalho: uma contribuição ao materialismo filosófico. Goiânia: EdUFG, 1997. Thomas Hobbes: passado e futuro. Goiânia: EdUFG, 2003.

HOBBES, Thomas. Leviathan. Introduction and Notes by J. C. A. Gaskin. New York: Oxford University Press, 1996.

IANNI, Octávio. Texto comentário em: "Cultura do povo e autoritarismo das elites". In: VALLE, E. et al. A cultura do povo. São Paulo: Cortez, 1988, p. 134-144.

LÉVI-STRAUSS, Claude. Jean-Jacques Rousseau, fundador de las ciencias del hombre. In: Presencia de Rousseau. Selección de José Sazbón. Buenos Aires: Nueva Visión, 1972.

MARX, Karl. Manuscritos económico-filosóficos. Trad.: Alex Marins. São Paulo: Martin Claret, 2003 (Coleção A Obra-Prima de Cada Autor, n. 68).

PAIVA, Wilson Alves de. Descentralização político-administrativa da educação no Brasil. Presença Pedagógica, Belo Horizonte: Editora Dimensão, v. 8, n. 48, p. 53-63, nov.-dez. 2002.

PISSARRA, Maria C. P. Rousseau: a política como exercício pedagógico. São Paulo: Moderna, 2002. ROUSSEAU, Jean-Jacques. Discurso sobre a origem e os fundamentos da desigualdade entre os homens. Trad. do francês: Iracema G. Soares e Maria C. R. Nagle. Brasília/São Paulo: Edunb/Ática, 1989. Emilio ou da educação. Trad.: Sérgio Milliet. 2. ed. São Paulo: Difel, 1973.

. Do contrato social ou princípios do direito político. Trad.: Lourdes Santos Machado. Introd. e notas: Paul Arbousse-Bastide e Lourival Machado. São Paulo: Nova Cultural, 1999 (Coleção Os Pensadores). VALLE, Edênio et al. A cultura do povo. São Paulo: Cortez, 1988.

VOLPE, Galvano Della. Rousseau e Marx: liberdade igualitária. Porto: Edições 70, 1982. 


\section{Popular festivities and education: a case study based on Rousseau's reflections}

Abstract

The author tries to establish a relationship between Rousseau's thinking about popular festivities and a cultural event which takes place in a small county in northern Brazil, as a result of the author's field research. He also explores the actuality of the Geneva thinker, with his ideas of sensibility, solidarity, liberty and equality as a counterpoint to the increasing dehumanization in present days, as processed by socio-economic inequality, globalization and mechanization of social relations. In the end, the paper tries to outline the role of education and particularly, that of schools and other public educational institutions in promoting human ideals, as those defended by Rousseau .

Keywords: Education. Culture. Folk culture. Rousseau. Case study.

\section{Fête populaire et éducation : une étude de cas devant les réflexions de Rousseau}

Résumé

L'auteur cherche à établir une relation entre la pensée de Jean-Jacques Rousseau au sujet de fêtes populaires, tel qu'un festival culturel qui se réalise annuellement dans une petite municipalité du nord brésilien, comme résultat de sa recherche sur le champ. Il explore aussi l'actualité du penseur genevois avec ses idées de valorisation de la sensibilité, solidarité, liberté et égalité comme contrepoids à l'actuelle inhumanisation processée par l'inégalité socio-économique, la globalisation et la mécanisation des relations sociales. En dernier lieu, le texte cherche à mettre en relief le rôle de l'éducation et précisément, des écoles et institutions publiques éducationnelles dans la promotion et valorisation des idéaux humains, défendus par Rousseau.

Mots clefs : Éducation. Culture. Culture populaire. Rousseau. Étude de cas.

\section{Fiesta popular y educación: un estudio de caso acerca de las reflexiones de Rousseau \\ Resumen}

El autor busca establecer una relación entre el pensamiento de Jean-Jacques Rousseau acerca de las fiestas populares, con un festival cultural que es realizado anualmente en un pequeño municipio del norte brasileño. Intenta explorar también la actualidad del pensador de Genebra, con sus ideas de valoración de la sensibilidad, de la solidariedad, de la libertad y de la igualdad como contrapunto a la actual deshumanización procesada por la desigualdad socioeconómica, globalización y mecanización de las relaciones sociales. Por último, el texto busca enfatizar el papel de la educación y, precisamente, de las escuelas e instituciones públicas educacionales en la promoción y valoración de los ideales humanos, defendidos por Rousseau.

Palabras-clave: Educación. Cultura. Cultura popular. Rousseau. Estudio de caso.

Recebido: 04.05 .2005

Aceito 26.07.2005 
